\title{
Development of Preventive Maintenance Guidelines for Architectural Components on Government Building Based on Work Breakdown Structure
}

\author{
Luki Wijaya*, Yusuf Latief, Rossy Armyn Machfudiyanto \\ Faculty of Engineering, Universitas Indonesia (UI), Depok, Indonesia \\ Received February 25, 2020; Revised May 20, 2020; Accepted May 30, 2020
}

Copyright $(02020$ by authors, all rights reserved. Authors agree that this article remains permanently open access under the terms of the Creative Commons Attribution License 4.0 International License

\begin{abstract}
To reduce the occurrence of damage to government buildings, the efforts for preventive maintenance work must be made. In a building's preventive maintenance work process, the scope of work can be arranged using Work Breakdown Structure (WBS), so that it becomes structured and activity-oriented. However, in the application of government buildings, there are no guidelines for preventive maintenance work that is standardized by WBS. Therefore, developing guidelines for preventive maintenance work is important to improve maintenance and upkeep on a work package. The purpose of this research is to develop the guidelines for preventive maintenance work based on Work Breakdown Structure (WBS) on the architectural components of government buildings. The research methodology comprises several steps, named the literature study, analysis of archives with data and information from previously related research and projects, case studies, as well as through the validation of experts. The results of this study are WBS-based preventive maintenance work guidelines for architectural components of government buildings that can improve the quality of buildings and the effectiveness and efficiency of building maintenance and upkeep.
\end{abstract}

Keywords Government Building, Guideline, Preventive Maintenance, Work Breakdown Structure

\section{Introduction}

According to Indonesian Law No. 28/2002 concerning Buildings, a building is a physical form of the result of construction work which is integrated with its footgold, partly or wholly above and/or in land and/or water, whichgives the function as a place for humans to carry out their activities, whether it is for residential, religious, business, social, cultural, as well as special activities.
Referring to Regulation of the Ministry of Public Works No. 45/PRT/ M/2007, one of the type is state buildings that is used for official purposes and constitute as a state property. Facilities and infrastructure contained in the building in the form of important components are interrelated with one another in order to achieve the function of the building to provide comfort and safety for its users (Assafat \& Prasetyo, 2011).

Basically, the buildings that are used for a long time will suffer damage to various aspects, one of which is the architectural component of the building, this condition will result in a decline in quality and ultimately can cause the building to collapse (Sing, Chan, \& Leung, 2015). Referring to Regulation of the Ministry of Public Works No. 24/PRT/M/2008, government buildings are buildings that function as centers of government activity and buildings for official purposes owned by government and managed funds come from the state budget and other legal benefits, aimed at achieving national welfare. Therefore, government buildings are suitable to represent their goals maintenance management. The multitude of damage experienced is caused by the lack of maintenances on government buildings (Suffian, 2011). Lack of attention to the maintenance and upkeep of architectural components can reduce the level of satisfaction of building occupants (Au-Yong, Ali, \& Ahmad, 2014). Building maintenance aims to minimize the cost of repairs, minimize the cost of energy use, increase user satisfaction, increase the efficiency of activities, and minimize potential safety problems.

In building maintenance and upkeep, there are four commonly used strategies, named corrective, condition-based, prediction, and preventive strategy (Kim, 2018). Preventive maintenance work can include tasks or actions taken to prevent the need for repairs (Ebelling, 1997). Preventive maintenance is an upkeep activity carried out on a scheduled basis, usually done periodically (Assauri, 2008). Preventive maintenance involves upkeep 
work such as periodic inspections (weekly, monthly, biennially), monitoring, cleaning, maintenance, lubrication, adjustment, alignment, repair and replacement of building components and systems before a system failure or damage occurs (Moghaddam \& Usher, 2010). Furthermore, preventive maintenance is based on characteristics of component reliability and aims to reduce the possibility of failure of a component in buildings (Fouladgar, Yazdani-Chamzini, \& Lashgari, 2012). To prevent the failures, preventive maintenance can indicate the right time to carry out maintenance or upkeep work that needs to be done (Yang, 2004).

In the process of preventive maintenance work of a building, the scope of work can be arranged using the Work Breakdown Structure (WBS). WBS is a process of breaking down from project work into smaller and more manageable components (PMBOK, 2017). WBS is a structured grouping and oriented on the activities and work contained in the project that defines the overall scope of the project (Hans, 2013). WBS is a tool for project management because it provides a basis for planning, scheduling, controlling, assignment of responsibilities and information management thus WBS can be used in any way including care and maintenance (Ibrahim, 2009) (Park $\&$ Cai, 2017). Accordingly, WBS plays an important role in sharing information about buildings and can help in developing preventive maintenance guidelines. Therefore, it is necessary to develop the guidelines for WBS-based preventive maintenance work for architectural work in government buildings.

\section{Research Objective}

The objectives of this research are:

1. To identify the architectural component work packages in government buildings that are required for preventive maintenance work.

2. To identify the current procedures and guidelines used in the preventive maintenance work of architectural components in government buildings.

3 . To create the preventive maintenance work guidelines on architectural components in government buildings based on WBS.

\section{Literature Review}

\section{Work Breakdown Structure (WBS)}

Work breakdown structure (WBS) forms the basis of most projects. WBS is an activity that describes the components of the entire scope of works in a project. WBS is a hierarchical decomposition of work oriented to the total deliverables to be carried out by the project team in order to achieve the project objectives and produce the required deliverables (PMBOK, 2017). WBS is a breakdown of deliverables and project work into smaller components that can be better managed the project work (Farizi \& LatieF, 2018). WBS is a dynamic document used to manage the scope of work as a whole. WBS has several levels consisting of two main levels, named the primary level (from the name of the project to the work package) and the complementary level (activities and resources) (Rianty, Latief, \& Riantini, 2018). Specifically, in the case of building maintenance and upkeep, WBS structures were introduced by the developmentof guidelines for building maintenance based on WBS increase building performance (Aryaningrum, Latief, \& Riantini, 2018). The structure of WBS is further defined in Table $\mathbf{1}$ below.

\section{Preventive Maintenance}

Obviously, the objective of building management is to maintain the value of the building and is responsible for maintenance functions of building as it is designed purpose (A. Crespo Marquez, Gomez Fernandez, Parra Marquez, \& Gonzalez, 2009) (Lam, 2010). The building maintenance is an effort to avoid the damage of building components due to obsolescence of buildings before the age is over (Latief, Armyn Machfudiyanto, Susilo Soepandji, Khairina, \& Aldesty, 2018). The maintenance works of implementation is categorized into four activities: planning, implementation, maintenance, and maintenance supervision (Armyn Machfudiyanto, Latief, Susilo Soepandji, \& Anggia Putri, 2018). Referring to Regulation of the Ministry of Public Works No. 24/PRT/M/2008, the preventive maintenance is an activity of maintaining the reliability of buildings and their infrastructure and facilities so that buildings are always worth for the function. Preventive maintenance is maintenance/upkeep activity that is carried out on a scheduled basis, generally on a periodic basis, in which a set of maintenance tasks such as inspection and repair, replacement, cleaning, lubrication, adjustment, and equalization (Ebelling, 1997) (Assauri, 2008) (Moghaddam \& Usher, 2010). Preventive maintenance is usually performed periodically on the critical components/elements to keep the components/elements performance function as it is designed (Basri, 2017). Preventive maintenance is an effective approach to improve the reliability and quality of a system and its components in a building. To prevent failure, preventive maintenance can indicate the right time to carry out maintenance/upkeep work that needs to be done (Yang, 2004).

Table 1. Structure WBS of Buildings

\begin{tabular}{|c|c|c|c|c|c|c|}
\hline WBS Level 1: & WBS Level 2: & WBS Level 3: & WBS Level 4: & WBS Level 5: & WBS Level 6: & WBS Level 7: \\
\hline Project Name & $\begin{array}{c}\text { Primary Elements of } \\
\text { Construction / Works } \\
\text { Cluster }\end{array}$ & Locations & $\begin{array}{l}\text { Sub Elements / } \\
\text { Job Type }\end{array}$ & Work Package & Activities & Resources \\
\hline
\end{tabular}




\section{Guideline for Preventive Maintenance Work in Buildings}

According to Regulation of the Ministry of Public Works No. 29/PRT/M/2006, the guideline is intended as a reference in meeting the technical requirements of buildings. Guidelines for maintenance and upkeep of buildings that are used as a reference in the framework of activities regulating and controlling the organization of buildings are needed for the process of building utilization. Referring to Regulation of the Ministry of Public Works No. 24/PRT/M/2008, this guideline aims to realize the use of buildings that meet the safety, health, comfort and convenience requirements as well as efficiency, harmony and in tune with the environment.

\section{Research Metodology}

The research methodology comprises several steps, named the study of literature, analysis of archives with data and information from previously research related and projects, case studies, and through the validation of experts to answer all research objectives, as follows: (1) identifying the architectural component work packages of government buildings that require preventive maintenance work on data collected from literature analysis, analysis of previous project archives, and asking experts to validate them; (2) furthermore, identifying preventive maintenance measures and schedules for periodic inspection of architectural components of government buildings, data collected from literature analysis, analysis of previous project archives, and ask experts to validate; (3) next, creating a WBS-based preventive maintenance guideline for architectural components of government buildings by requesting final validation by experts regarding the guidelines made. The explanations related to the flow of this research more clearly can be seen in Figure 1 below.

In this research, a case study is conducted on one of the government buildings in Indonesia and refers to Regulation of the Ministry of Public Works No. 24/PRT/M/2008, concerning the guidelines for building maintenance and upkeep and refering to Regulation of the Ministry of Public Works No. 16/PRT/M/2010, about the technical guidelines for periodic inspection of buildings. Regarding the schedule of periodic inspections on preventive maintenance work on the building's component of government buildings based on preventive maintenance in the work activities of each work package or alternative design, this periodic inspection schedule is validated by experts who are then developed to serve as guidelines for preventive maintenance work on architectural components in government buildings.

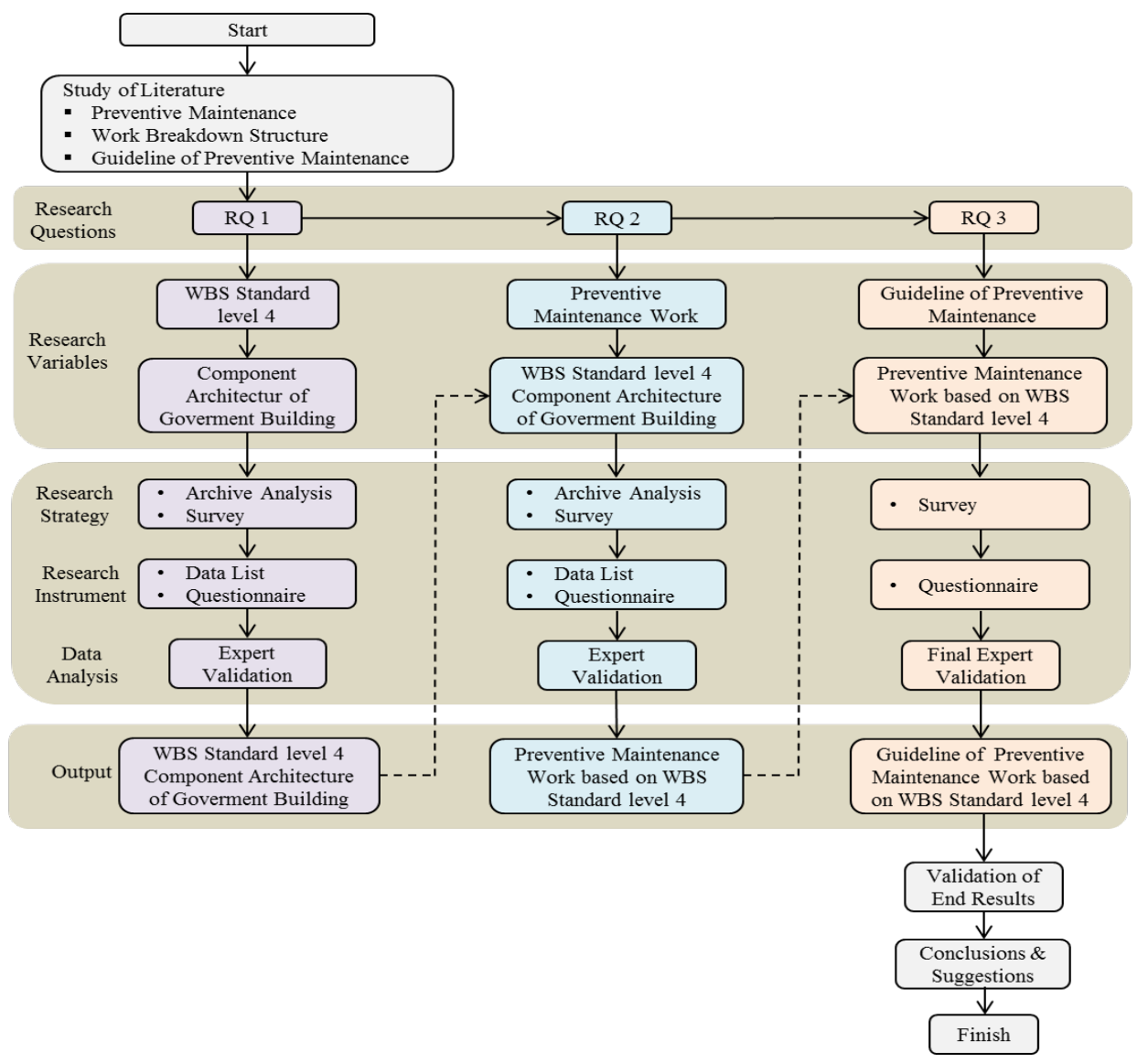

Figure 1. The Research Flow Diagram 


\section{Result and Discussion}

Based on conducted research, the following results are obtained.

1. WBS standard of preventive maintenance work of architectural components in government buildings

In the preventive maintenance work of architectural components in government buildings that are based on WBS, named the primary level (from the name of the project to the work package) (Rianty et al., 2018). WBS level 4 has been validated by experts with the following results:

a.WBS Level 1 (Project Name): This level is the highest and represents the entire project. In this study, level 1 is preventive maintenance of government buildings.

b.WBS Level 2 (Work Section): This level is the decomposition of project elements consisting of structural, architectural, mechanical, electrical, landscape, and housekeeping elements. In this study, the object of research is the architectural element. c. WBS Level 3 (Sub-Work Section): This level is a further decomposition of architectural elements. This level consists of parking and pedestrian facilities, smoking facilities, exit facilities, floor work, wall work, ceiling work, door and window work, hardware work, sanitation work, facade work, roofing work and other works.

d.WBS Level 4 (Work Package): This level is the lowest level of the WBS primary level. This level represents the decomposition of each type of work.

Some of the results from the WBS decomposition of standard preventive maintenance work at the primary level are presented in Figure 2. The types of work and work packages determine the findings in the requirements of government buildings. Meanwhile, at WBS level 3, there are 12 types of work contained in the validated architecture of government buildings. At WBS Level 3, there are 12 types of validated works. At WBS level 4, there are 41 work packages validated by experts. Meanwhile, some of them are illustrated in the tree diagram in Figure $\mathbf{2}$ below.

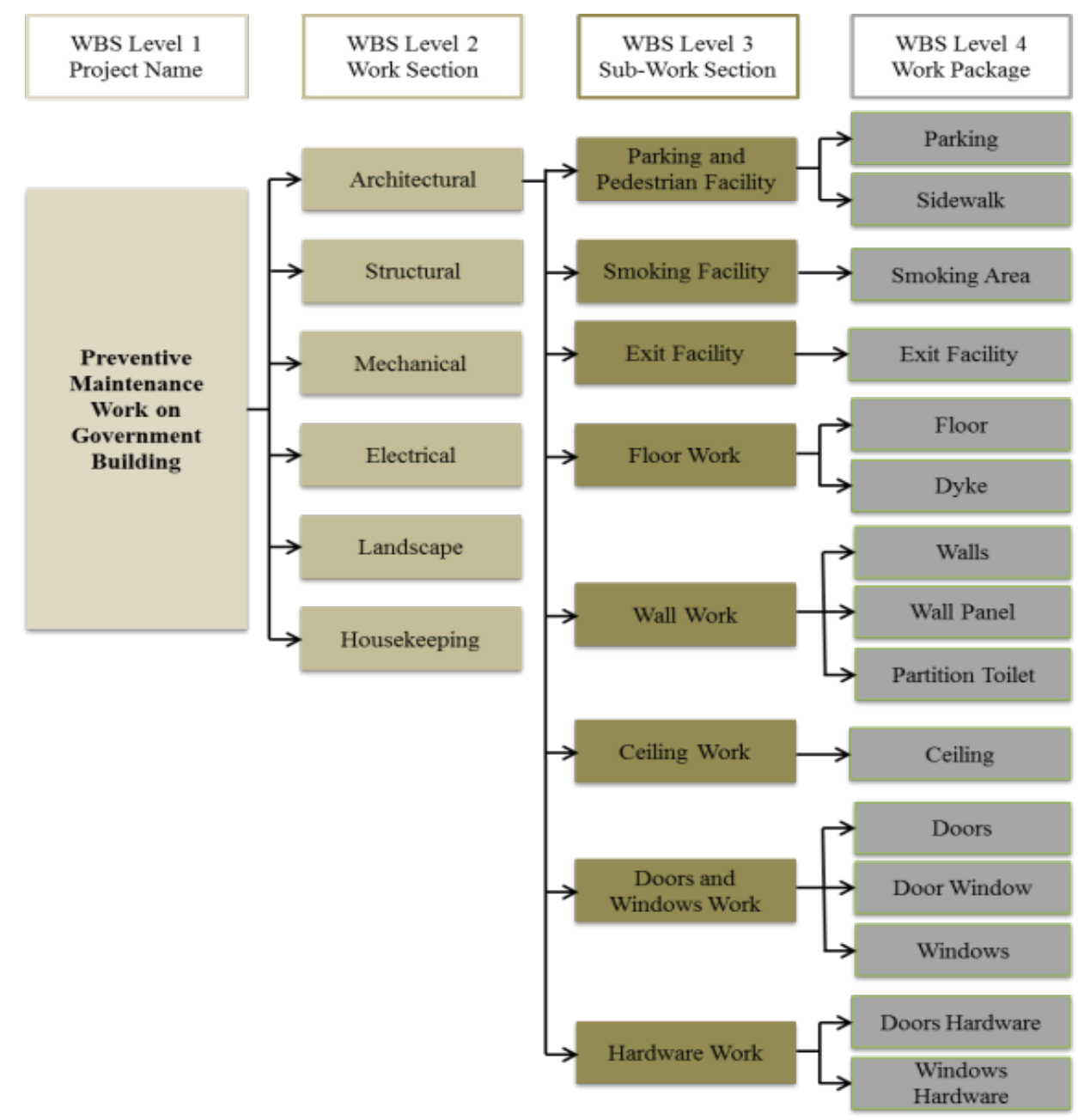

Figure 2. WBS Standard Component Architecture of Government Building 
In addition to the primary level WBS, there is a complementary level WBS in the preventive maintenance work of architectural components in government buildings, named alternative designs or methods, activities and resources. Alternative design or method is the construction implementation method which is basically a combination of work procedures and implementation techniques, which are the core of all activities in the construction management system (Jawat, 2015). In this study, there are 75 alternative designs. Table 2 provides an illustration of a number of preventive maintenance work packages for architectural components of government buildings with each alternative design or method validated by the expert.

Table 2.Alternative Design Preventive Maintenance Work Component Architectural Government Building

\begin{tabular}{|c|c|c|c|c|c|}
\hline \multicolumn{2}{|c|}{ WBS Level 3} & \multicolumn{2}{|c|}{ WBS Level 4} & \multicolumn{2}{|r|}{ Alternative Design } \\
\hline KODE & DETAIL & KODE & DETAIL & KODE & DETAIL \\
\hline \multirow[b]{2}{*}{ X3.1 } & \multirow{2}{*}{$\begin{array}{c}\text { Parking and } \\
\text { pedestrian } \\
\text { Facility }\end{array}$} & \multirow[b]{2}{*}{$\mathrm{X} 4.1$} & \multirow[b]{2}{*}{ Parking } & $\mathrm{X} 4.1 .1$ & Bicycle Parking \\
\hline & & & & $\mathrm{X} 4.1 .2$ & Motorized Parking \\
\hline \multirow{10}{*}{$\mathrm{X} 3.4$} & \multirow{10}{*}{ Floor Work } & \multirow{9}{*}{$\mathrm{X} 4.5$} & \multirow{9}{*}{ Floor } & $\mathrm{X} 4.5 .1$ & Floor Hardener \\
\hline & & & & $\mathrm{X} 4.5 .2$ & Corridor Area Ceramic Floor \\
\hline & & & & $\mathrm{X} 4.5 .3$ & Dry Area Ceramic Floor \\
\hline & & & & $\mathrm{X} 4.5 .4$ & Wet Area Ceramic Floor \\
\hline & & & & $\mathrm{X} 4.5 .5$ & Fire Stair Ceramic Floor \\
\hline & & & & $\mathrm{X} 4.5 .6$ & Waterprof Concrete Coating Floor \\
\hline & & & & $\mathrm{X} 4.5 .7$ & Waterprof Concrete Membrane Flooring \\
\hline & & & & $\mathrm{X} 4.5 .8$ & Screed Floor \\
\hline & & & & $\mathrm{X} 4.5 .9$ & Wooden Deck Floor \\
\hline & & $\mathrm{X} 4.6$ & Dyke & $\mathrm{X} 4.6 .1$ & Brick Dyke \\
\hline \multirow{11}{*}{$\mathrm{X} 3.5$} & \multirow{11}{*}{ Wall Work } & \multirow{10}{*}{$\mathrm{X} 4.7$} & \multirow{10}{*}{ Wall } & $\mathrm{X} 4.7 .1$ & Wet Area Ceramic Walls \\
\hline & & & & $\mathrm{X} 4.7 .2$ & Parapet Brick Wall \\
\hline & & & & $\mathrm{X} 4.7 .3$ & Fire Rated Wall \\
\hline & & & & $\mathrm{X} 4.7 .4$ & Tempered glass Wall \\
\hline & & & & $\mathrm{X} 4.7 .5$ & Mozaik \\
\hline & & & & $\mathrm{X} 4.7 .6$ & Marble Layer Walls \\
\hline & & & & $\mathrm{X} 4.7 .7$ & Clading Aluminium Composit Cover Wall \\
\hline & & & & $\mathrm{X} 4.7 .8$ & Gypsum Partition Walls \\
\hline & & & & $\mathrm{X} 4.7 .9$ & Drywall \\
\hline & & & & $\mathrm{X} 4.7 .10$ & Fiber Cement Board \\
\hline & & $\mathrm{X} 4.8$ & Wall Panel & $\mathrm{X} 4.8 .1$ & Plywood Finish Hpl \\
\hline \multirow{3}{*}{$\mathrm{X} 3.6$} & \multirow{3}{*}{ Ceiling Work } & \multirow{3}{*}{$\mathrm{X} 4.10$} & & $\mathrm{X} 4.10 .1$ & Acoustic Ceiling \\
\hline & & & Ceiling & $\mathrm{X} 4.10 .2$ & Gypsum Ceiling \\
\hline & & & & $\mathrm{X} 4.10 .3$ & Water Resistant Gypsum Ceiling \\
\hline & & & & $\mathrm{X} 4.11 .1$ & Wood Door \\
\hline & & & & $\mathrm{X} 4.11 .3$ & Aluminum Glass Door \\
\hline & & & & $\mathrm{X} 4.11 .4$ & Iron Door with Panel Iron Frame \\
\hline & & $\mathrm{X} 4.11$ & Doors & $\mathrm{X} 4.11 .5$ & Fire Ladder Door \\
\hline & Doors and & & & $\mathrm{X} 4.11 .6$ & Frameless Glass Door \\
\hline X3.7 & Windows & & & $\mathrm{X} 4.11 .7$ & Iron Plate Shaft Door \\
\hline & Work & & & $\mathrm{X} 4.11 .8$ & Plywood Panel Door with Aluminum Frame \\
\hline & & & & $\mathrm{X} 4.11 .9$ & Sliding door, Rolling Door, Folding door \\
\hline & & & & $\mathrm{X} 4.12 .1$ & Aluminum Glass Door Window Frame \\
\hline & & $\mathrm{X} 4.12$ & Door Window & $\mathrm{X} 4.12 .2$ & Entrance Glass Door Window \\
\hline & & & & $\mathrm{X} 4.13 .1$ & Aluminum Glass Window Frame \\
\hline & & $X 4.13$ & Window & $\mathrm{X} 4.13 .2$ & Bovenlicht Aluminum Glass Window Frame \\
\hline & & & & $\mathrm{X} 4.14 .1$ & Single Swing Door \\
\hline & & & & $\mathrm{X} 4.14 .2$ & Double Swing Door \\
\hline & & & & $\mathrm{X} 4.14 .3$ & Urinoir \\
\hline$\times 38$ & Hardware & X414 & Door Hardware & $\mathrm{X} 4.14 .4$ & Automatic Door \\
\hline X3.8 & Work & $\mathrm{X} 4.14$ & Door Hardware & $\mathrm{X} 4.14 .5$ & Fire Ladder Door \\
\hline & & & & $\mathrm{X} 4.14 .6$ & Keys, Latches, and Hinges \\
\hline & & & & $\mathrm{X} 4.14 .7$ & Door Closer \\
\hline & & & & $\mathrm{X} 4.14 .8$ & Accesories Door Stopper \\
\hline & & X415 & Toilet & $\mathrm{X} 4.15 .1$ & Toilet Seat \\
\hline X3.9 & Sanitair Work & $X 4.15$ & Toilet & $\mathrm{X} 4.15 .2$ & Toilet Squat \\
\hline & & $\mathrm{X} 4.21$ & Tap & $\mathrm{X} 4.21 .1$ & Wall Tap \\
\hline
\end{tabular}




\begin{tabular}{|c|c|c|c|c|c|}
\hline & & & & $\mathrm{X} 4.21 .2$ & Table Tap \\
\hline \multirow{4}{*}{$\mathrm{X} 3.10$} & \multirow{4}{*}{ Facade Work } & \multirow{4}{*}{$\mathrm{X} 4.27$} & \multirow{4}{*}{ Wall } & $\mathrm{X} 4.27 .1$ & Sticky Brick Wall \\
\hline & & & & $\mathrm{X} 4.27 .2$ & Curtain Wall \\
\hline & & & & $\mathrm{X} 4.27 .3$ & Sunscreen grille \\
\hline & & & & $\mathrm{X} 4.27 .4$ & Alumunium Extruded \\
\hline \multirow{7}{*}{ X3.11 } & \multirow{7}{*}{ Roof Work } & $\mathrm{X} 4.28$ & Roof Insulation & $\mathrm{X} 4.28 .1$ & Alumunium Foil Insulation \\
\hline & & \multirow{6}{*}{$\mathrm{X} 4.29$} & \multirow{6}{*}{ Roof Coating } & $\mathrm{X} 4.29 .1$ & Waterprof Concrete Membrane Roof \\
\hline & & & & $\mathrm{X} 4.29 . .2$ & Waterprof Concrete Coating Roof \\
\hline & & & & $\mathrm{X} 4.29 .3$ & Waterprof Concrete Integral Roof \\
\hline & & & & $\mathrm{X} 4.29 . .4$ & Fiberglass Roof \\
\hline & & & & $\mathrm{X} 4.29 .5$ & Polycarbonate Roof \\
\hline & & & & $\mathrm{X} 4.29 . .6$ & Glass Roof \\
\hline \multirow{12}{*}{$\mathrm{X} 3.12$} & \multirow{12}{*}{ Other Work } & $\mathrm{X} 4.30$ & Railing & $\mathrm{X} 4.30 .1$ & Railing Fire Ladder \\
\hline & & $\mathrm{X} 4.32$ & Wheel Stopper & $\mathrm{X} 4.32 .1$ & Wheel Stopper Concrete \\
\hline & & $\mathrm{X} 4.34$ & Convex mirror & $\mathrm{X} 4.34 .1$ & Convex Mirror Pole \\
\hline & & $\mathrm{X} 4.35$ & Signpost & $\mathrm{X} 4.35 .1$ & Pole Signs \\
\hline & & $\mathrm{X} 4.37$ & Gutter & $\mathrm{X} 4.37 .1$ & Open Gutter with Grill \\
\hline & & \multirow{2}{*}{$\mathrm{X} 4.38$} & \multirow{2}{*}{ Cover Column } & $\mathrm{X} 4.118$ & Panel Plywood Finish HPL \\
\hline & & & & $\mathrm{X} 4.119$ & Panel ACP \\
\hline & & \multirow{3}{*}{$\mathrm{X} 4.40$} & \multirow{3}{*}{ Canopy } & $\mathrm{X} 4.40 .1$ & ACP Canopy \\
\hline & & & & $\mathrm{X} 4.41 .2$ & Glass Canopy \\
\hline & & & & $\mathrm{X} 4.41 .3$ & Tempered Glass Canopy \\
\hline & & \multirow{2}{*}{$\mathrm{X} 4.41$} & \multirow{2}{*}{ Grill } & $\mathrm{X} 4.41 .1$ & Grill Alumunium \\
\hline & & & & $\mathrm{X} 4.41 .2$ & Grill Steel \\
\hline
\end{tabular}

Table 3. Model of WBS Preventive Maintenance Work on Government Building

\begin{tabular}{|c|c|c|c|c|}
\hline $\begin{array}{l}\text { WBS Level } 1 \\
\text { Project Name }\end{array}$ & $\begin{array}{l}\text { WBS Level } 2 \\
\text { Work Section }\end{array}$ & $\begin{array}{c}\text { WBS Level } 3 \\
\text { Sub-Work Section }\end{array}$ & $\begin{array}{c}\text { WBS Level } 4 \\
\text { Work Package }\end{array}$ & $\begin{array}{c}\text { Alternative } \\
\text { Design/Method }\end{array}$ \\
\hline \multirow{3}{*}{$\begin{array}{c}\text { Preventive Maintenance } \\
\text { Work on Government } \\
\text { Building }\end{array}$} & \multirow{3}{*}{ Architectural } & \multirow{3}{*}{ Ceiling Work } & \multirow{3}{*}{ Ceiling } & Acoustic Ceiling \\
\hline & & & & Gypsum Ceiling \\
\hline & & & & $\begin{array}{c}\text { Water Resistant Gypsum } \\
\text { Ceiling }\end{array}$ \\
\hline
\end{tabular}

After determining the design alternatives in the preventive maintenance work on architectural components of government buildings, each alternative design has their own work activities. Work activity is a WBS process using decomposition taken from a work package that identifies activities needed to complete a project (PMBOK, 2017). Work activities have the purpose of identifying specific tasks that need to be done for completing the project in accordance with the target. The main input is the basic scope consisting of agreed project scope statements, WBS, and WBS dictionary. The work activities in the preventive maintenance work on architectural components of government buildings are inspection, maintenance, and upkeep. According to Regulation of the Ministry of Public Works No. 16/PRT/M/2010, the inspection is an activity taken on all architectural components which are carried out within a certain period of time in order to state the appropriateness of the building's functions. Maintenance is a step taken for prevention that is carried out periodically. Upkeep is a follow-up step of maintenance activities to maintain the condition of the building to be function-worthy. These work activities will be used in the preventive maintenance work actions. The Table $\mathbf{3}$ is a WBS model of preventive maintenance work on architectural components in government buildings.
2. Procedures for preventive maintenance work on Architectural Components of Government buildings

Based on the standard WBS, the preventive maintenance measures are reviewed from each work activity on a work package or an alternative design from the architecture component of a government building. In the parking and pedestrian facilities work, the preventive measures are checking the surface of the road around the facility every month, carrying out cleaning of dirt, grass, dead bushes every 3 months, and painting the facilities annually. In floor work, the preventive maintenance measures taken are checking the condition of the floor every month, cleaningand vacuuming the floor every day. In wall work, the preventive maintenance measures are carried out by inspecting the walls for cracks and deformations every 3 months and cleaning the walls from dirt every week. In ceiling work, the preventive maintenance measures are carried out by checking the ceiling protectors, cleaning the dust and dirt every month, and repainting the ceiling every 6 months. In door and window work, the preventive maintenance measures taken are checking the operation and locking for 3 months, lubricating the hinges, opening the door and keyhole every 3 months. In roof work, the preventive maintenance measures taken are checking the roof for cracks and damage every 3 months, cleaning the 
surface of the roof from dirt that is stuck every 3 months, and giving a leak-proof coating every 6 months. In railing work, the preventive maintenance measures are carried out by cleaning and wiping the railing against the dirt and stains every week, and replacing damaged layers with new ones each year. In canopy work, the preventive maintenance measures are carried out by tightening the bolts in the canopy every 6 months, painting the canopy annually, and replacing or repairing sealants that are contained in the canopy every year. The following of Table 4 is the illustration of the preventive maintenance procedure.

Table 4. The Preventive Maintenance Procedure

\begin{tabular}{|c|c|c|c|}
\hline \multicolumn{4}{|c|}{ Standard Procedure Preventive Maintenance - Gypsum Ceiling } \\
\hline \multicolumn{2}{|r|}{ Activities } & \multicolumn{2}{|c|}{$\begin{array}{c}\text { Periodic Inspection } \\
\text { Schedule }\end{array}$} \\
\hline \multicolumn{4}{|c|}{ Inspection } \\
\hline$\bullet$ & Make sure the ceiling remains dry & $\bullet$ & Every 3 month \\
\hline$\bullet$ & $\begin{array}{l}\text { Check the ceiling protection } \\
\text { devices }\end{array}$ & $\bullet$ & Every 3 month \\
\hline$\bullet$ & $\begin{array}{l}\text { Check for damage and cracks in the } \\
\text { ceiling }\end{array}$ & $\bullet$ & Every 3 month \\
\hline \multicolumn{4}{|c|}{ Maintenance } \\
\hline$\bullet$ & $\begin{array}{l}\text { Clean the dust regularly or clean it } \\
\text { with a damp cloth }\end{array}$ & $\bullet$ & Every month \\
\hline$\bullet$ & Make sure the surface is always dry & $\bullet$ & Every month \\
\hline$\bullet$ & Seal cracks and joints & $\bullet$ & Every month \\
\hline \multicolumn{4}{|c|}{ Upkeep } \\
\hline$\bullet$ & Do a ceiling repaint & $\bullet$ & Every 6 month \\
\hline$\bullet$ & $\begin{array}{l}\text { Apply preservatives, or other } \\
\text { suitable protective sealants }\end{array}$ & $\bullet$ & Every 6 month \\
\hline
\end{tabular}

3. WBS-Based Preventive Maintenance Guidelines for Architectural Components in Government Buildings

After defining the WBS, the alternative designs, the preventive maintenance measures for each work package activity and design, these alternative guidelines are built. The important work, the preventive maintenance, and the periodic inspection schedules are stated in this guide, as described in Figure 3.

\section{Conclusions}

In answering the objectives of this study, the following conclusions can be drawn:

a. WBS level 4 Work Package: At WBS level 4, there are 41 work packages and 75 alternative designs that are used in preventive maintenance work on architectural components of government buildings.

b. There are several preventive maintenance measures for each work activity in the form of inspection and maintenance on the work package, along with a regular inspection schedule for each action.

c. The result of this study is an implementation guidance document containing the identification of WBS from level 1 to level 4 including the alternative designs, work activities, preventive maintenance measures and periodic inspection schedules.

\begin{tabular}{|c|c|c|c|}
\hline \multicolumn{4}{|c|}{ PREVENTIVE MAINTENANCE WORK GUIDELINES FOR GOVERNMENT BUILDING } \\
\hline \multicolumn{2}{|c|}{ CODE WBS } & \multicolumn{2}{|c|}{ DESCRIPTION } \\
\hline \multicolumn{2}{|c|}{ WBS Level 2} & WORK SECTION & Architecture \\
\hline \multicolumn{2}{|c|}{ WBS Level 3} & SUB-WORK SECTION & Ceiling Work \\
\hline \multicolumn{2}{|c|}{ WBS Level 4} & WORK PACKAGE & Ceiling \\
\hline \multicolumn{3}{|r|}{ ALTERNATIVE DESIGN } & Ceilin Gypsum \\
\hline Activities & \multicolumn{2}{|c|}{ Preventive Maintenance Procedures } & Periodic Inspection Schedule \\
\hline \multirow{3}{*}{ Inspection } & \multicolumn{2}{|c|}{ - Make sure the ceiling remains dry } & - Every 3 month \\
\hline & \multicolumn{2}{|c|}{ - Check the ceiling protection devices } & - Every 3 month \\
\hline & \multicolumn{2}{|c|}{ - Check for damage and cracks in the ceiling } & - Every 3 month \\
\hline \multirow{3}{*}{ Maintenance } & \multicolumn{2}{|c|}{ - Clean the dust regularly or clean it with a damp cloth. } & - Every month \\
\hline & \multicolumn{2}{|c|}{ - Make sure the surface is always dry } & - Every month \\
\hline & \multicolumn{2}{|c|}{ - Seal cracks and joints } & - Every month \\
\hline \multirow{2}{*}{ Upkeep } & \multicolumn{2}{|c|}{ - Do a ceiling repaint } & - Every 6 month \\
\hline & \multicolumn{2}{|c|}{ - Apply preservatives, or other suitable protective sealants } & - Every 6 month \\
\hline
\end{tabular}

Figure 3. The Guideline for Preventive Maintenance Work 


\section{Acknowledgement}

The authors would like to thank the members of the Maintenance Building Team who have helped researchers to provide support in the form of both financial and moral support in completing this research.

\section{REFERENCES}

[1] A. Crespo Marquez, P. M. d. L., Gomez Fernandez, J. F., Parra Marquez, C., \& Gonzalez, V. (2009). The Maintenance Management Framework: A Practical View To Maintenance Management. Journal of Quality in Maintenance Engineering, 669-674.

[2] Armyn Machfudiyanto, R., Latief, Y., Susilo Soepandji, B., \& Anggia Putri, P. (2018). Improving business processes to develop standard operation procedures on government building maintenance work in Indonesia. MATEC Web of Conferences, 195. https://doi.org/10.1051/matecconf/20181 9506006

[3] Aryaningrum, P., Latief, Y., \& Riantini, L..(2018). Development of Implementation Guidlines for Maintenance, Repairation and Determine Material Specifications for Mechanical Component Design in Government Own Green Building Based on Work Breakdown Structure. MATEC Web of Conferences, ICCEMS.

[4] Assafat, L., \& Prasetyo, M. . (2011). Level of Reliability Utility Electricity Building Level in Semarang City. Media Elektrika, p. 2.

[5] Assauri, S. (2008). Production and Operation Management Revised Edition. Indonesia: Faculty of Economy Universitas Indonesia.

[6] Au-Yong, C. P., Ali, A. S., \& Ahmad, F. (2014). Preventive Maintenance Characteristics towards Optimal Maintenance Performance: A Case Study of Office Buildings. World Journal of Engineering and Technology, 02(03), 1-6. https://doi.org/10.4236/wjet.2014.23b001

[7] Basri, R. (2017). Preventive Maintenance (PM) Planning: A Review. Journal of Quality in Maintenance Engineering, 23(2).

[8] Ebelling, C. E. (1997). Reliability and Maintainability Engineering. London: McGraw Hill Companies inc.

[9] Farizi, S. A., \& LatieF, Y. (2018). Development Of Standardized WBS (Work Breakdown Structure) For Planning The Schedule Based On Risk In Steel Bridge Construction Projects. IEOM Society International, 757-762.
[10] Fouladgar, M. M., Yazdani-Chamzini, A., \& Lashgari, A. (2012). Maintenance Strategy Selection Using AHP and COPRAS under Fuzzy Environment. International Journal of Strategic Property Management, 16(1), 85-104.

[11] Hans, R. T. (2013). Work Breakdown Structure: A Tool For Software Project Scope Verification. International Journal of Software Engineering \& Applications, 4(4), 19-25.

[12] Ibrahim, Y. M. (2009). Framework for a Generic Work Breakdown Structure for Building Projects. Construction Innovation, 388-405.

[13] Jawat, I. W. (2015). Method of Performing Foundation Work. Paduraksa, 4(2), 22-34.

[14] Kim, S. (2018). Evaluating Housing Maintenance Costs with Loss-Distribution Approach in South Korean Apartment Housing. Journal of Management in Engineering, 35(2).

[15] Lam, E. W. M. (2010). Benchmarking Success of Building Maintenance Projects. Emerald Group Publishing Limited, 28(5/6), 290-305.

[16] Latief, Y., Armyn Machfudiyanto, R., Susilo Soepandji, B., Khairina, \& Aldesty, R. (2018). The development of quality management systems in maintenance and monitoring the process of risk-based repair work in government buildings. MATEC Web of Conferences, 195. https://doi.org/10.1051/ matecconf $/ 201819506005$

[17] Moghaddam, M., \& Usher, J. S. (2010). Optimal Preventive Maintenance and Replacement Schedules with Variable Improvement Factor. Journal of Quality in Maintenance Engineering, 16(3), 271-287.

[18] Park, J., \& Cai, H. (2017). WBS-based dynamic multi-dimensional BIM database for total construction as-built documentation. Automation in Construction, 77, $15-23$.

[19] PMBOK. (2017). Project Management Body of Knowledge. USA: Project Management Institute.

[20] Rianty, M., Latief, Y., \& Riantini, L. S. (2018) Development of Risk-Based Standardized WBS (Work Breakdown Structure) for Quality Planning of High Rise Building Architectural Works. MATEC Web of Conferences, ICCEMS.

[21] Sing, M. C., Chan, H. C., \& Leung, A. (2015). Building Maintenance and Repair: Determining the Workforce Demand and Supply for a Mandatory Building-Inspection Scheme. Journal of Performance of Construction, 30(2).

[22] Suffian, A. (2011). Some Common Maintenance Problems and Building Defects. Procedia Engineering, 101-108.

[23] Yang, S. K. (2004). A Condition-Based Preventive Maintenance Arrangement for Thermal Power Plants. Electric Power Systems Research, 72(1), 49-62. 